\title{
Crucial Role of $\alpha 4$ and $\alpha 6$ Nicotinic Acetylcholine Receptor Subunits from Ventral Tegmental Area in Systemic Nicotine Self-Administration
}

\author{
S. Pons, ${ }^{1,2 *}$ L. Fattore, ${ }^{3,4 *}$ G. Cossu, ${ }^{5}$ S. Tolu, ${ }^{1,2}$ E. Porcu, ${ }^{5}$ J. M. McIntosh, ${ }^{6}$ J. P. Changeux, ${ }^{2}$ U. Maskos, ${ }^{1,2}$ and W. Fratta ${ }^{3,4,5}$ \\ ${ }^{1}$ Unité 'Neurobiologie intégrative des systèmes cholinergiques', Institut Pasteur, 75724 Paris Cedex 15, France, ${ }^{2}$ Centre National de la Recherche \\ Scientifique, Unité de Recherche Associée 2182, Institut Pasteur, 75724 Paris Cedex 15, France, ${ }^{3}$ Institute of Neuroscience, Consiglio Nazionale delle \\ Ricerche, Sezione di Cagliari, 09042 Monserrato, Italy, ${ }^{4}$ Centre of Excellence 'Neurobiology of Dependence' and ${ }^{5}$ Department of Neuroscience, Cittadella \\ Universitaria di Monserrato, University of Cagliari, 09042 Monserrato, Italy, and ${ }^{6}$ Departments of Biology and Psychiatry, University of Utah, Salt Lake City, \\ Utah 84112
}

The identification of the molecular mechanisms involved in nicotine addiction and its cognitive consequences is a worldwide priority for public health. Novel in vivo paradigms were developed to match this aim. Although the $\beta 2$ subunit of the neuronal nicotinic acetylcholine receptor (nAChR) has been shown to play a crucial role in mediating the reinforcement properties of nicotine, little is known about the contribution of the different $\alpha$ subunit partners of $\beta 2$ (i.e., $\alpha 4$ and $\alpha 6$ ), the homo-pentameric $\alpha 7$, and the brain areas other than the ventral tegmental area (VTA) involved in nicotine reinforcement. In this study, nicotine (8.7-52.6 $\mu \mathrm{g}$ free base $/ \mathrm{kg} / \mathrm{inf}) \mathrm{self}-$ administration was investigated with drug-naive mice deleted (K0) for the $\beta 2, \alpha 4, \alpha 6$ and $\alpha 7$ subunit genes, their wild-type (WT) controls, and $\mathrm{KO}$ mice in which the corresponding nAChR subunit was selectively re-expressed using a lentiviral vector (VEC mice). We show that WT mice, $\beta 2$-VEC mice with the $\beta 2$ subunit re-expressed exclusively in the VTA, $\alpha 4$-VEC mice with selective $\alpha 4$ re-expression in the VTA, $\alpha 6$-VEC mice with selective $\alpha 6$ re-expression in the VTA, and $\alpha 7$-K0 mice promptly self-administer nicotine intravenously, whereas $\beta 2-\mathrm{KO}, \beta 2-V E C$ in the substantia nigra, $\alpha 4-\mathrm{K} 0$ and $\alpha 6-\mathrm{K} 0$ mice do not respond to nicotine. We thus define the necessary and sufficient role of $\alpha 4 \beta 2$ - and $\alpha 6 \beta 2$-subunit containing nicotinic receptors ( $\alpha 4 \beta 2^{\star}$ - and $\alpha 6 \beta 2^{\star}$-nAChRs), but not $\alpha 7^{\star}$-nAChRs, present in cell bodies of the VTA, and their axons, for systemic nicotine reinforcement in drug-naive mice.

Key words: nicotinic acetylcholine receptor (nAChR); ventral tegmental area (VTA); lentiviral vector; nicotine; intravenous self-administration; drug-naive mice

\section{Introduction}

Nicotine is the principal substance responsible for tobacco addiction (Peto et al., 1996; Balfour, 2002; Silagy et al., 2004), but it also enhances attention and cognitive performance (Newhouse et al., 2004). Nicotine binds to neuronal nicotinic acetylcholine receptors (nAChRs), a heterogeneous family of pentameric ligandgated ion channels (Corringer et al., 2000; Changeux and Edelstein, 2005). In the brain, six $\alpha(\alpha 2-\alpha 7)$ and/or three $\beta(\beta 2-\beta 4)$

\footnotetext{
Received Aug. 8, 2008; revised Sept. 22, 2008; accepted 0ct. 9, 2008.

This work was supported by grants from the Agence Nationale pour la Recherche (ANR Neuroscience, Neurologie et Psychiatrie 2005), Institut Pasteur, the Collège de France, the Centre National de la Recherche Scientifique CNRS URA 2182, the Association de Recherche sur le Cancer (ARC), the Institut National du Cancer (INCa), Mission Interministérielle de Lutte contre la Drogue et la Toxicomanie (MILDT), the Fondation pour la Recherche Médicale (FRM), and European Commission Contracts 'Nicotine Dependence' (NIDE) and 'Nicotine and Ageing' to U.M. and J.-P.C, and National Institutes of Health Grants MH 53631, GM 48677, and DA12242 to J.M.M. We thank Jerry Stitzel for his generous gift of the mouse $\alpha 4$ subunit, Ines Ibanez-Tallon for the mouse $\alpha 6$-FLAG clone, Philippe Faure, Morgane Besson, Brian Molles, Sylvie Granon, and Arnaud Cressant for comments on this manuscript, and Barbara Tuveri for animal care.

*S. Pons and L. Fattore contributed equally to this work.

Correspondence should be addressed to either of the following: U. Maskos, E-mail: uwe.maskos@pasteur.fr, or W. Fratta, E-mail:wfratta@unica.it, at the above addresses.

DOI:10.1523/JNEUROSCI.3918-08.2008

Copyright $\odot 2008$ Society for Neuroscience $\quad 0270-6474 / 08 / 2812318-10 \$ 15.00 / 0$
}

subunits potentially assemble in multiple combinations with a broad diversity of pharmacological and electrophysiological properties (McGehee and Role, 1995; Le Novère et al., 2002). In genetically engineered mice lacking the $\beta 2$ subunit $(\beta 2-\mathrm{KO}$ mice), $\beta 2$ has been shown to contribute to cognitive functions and nicotine reinforcement (Picciotto et al., 1995, 1998; Granon et al., 2003). $\alpha 4$ subunit containing nicotinic receptors $\left(\alpha 4^{\star}\right.$ $n A C h R s)$ have been implicated in conditioned place preference for nicotine (Tapper et al., 2004), whereas the role of $\alpha 6^{*}$ $n A C h R s$ remains insufficiently characterized, although both of them are quantitatively expressed in dopaminergic (DAergic) neurons (Le Novère et al., 1996; Champtiaux et al., 2002, 2003). The ventral tegmental area (VTA) is considered the principal brain region mediating the reinforcing properties of multiple drugs of abuse, including nicotine, but its precise contribution is still debated (Laviolette and van der Kooy, 2004; Nashmi et al., 2007).

In the present study we address two important issues: the first concerns the mode of administration of nicotine. We attempted to identify the brain regions implicated when nicotine is selfadministered systemically rather than directly injected into the VTA (Maskos et al., 2005; Besson et al., 2006; David et al., 2006). 
We adopted intravenous nicotine self-administration (SA) because it is considered the animal paradigm most closely resembling smoking behavior in humans (Rose and Corrigall, 1997; Corrigall, 1999). In the past, drug SA studies have been conducted using chronic procedures in rodents, in which animals were used as their own controls (Koob and Weiss, 1990). Recently, studies have been published by several groups using an acute mouse model in which animals are tested in pairs using a contingent and a yoked control mouse, which enables rapid assessment of the reinforcing properties of a compound. Although this acute model is thought to assess the initiation rather than the chronic maintenance of drug-taking behavior, it was demonstrated that drug-naive mice acutely self-administer the same drugs that humans abuse, such as cocaine (Kuzmin et al., 1992, 1996c,d, 2000; Kuzmin and Johansson, 2000; Rasmussen et al., 2000; Blokhina et al., 2005; Lesscher et al., 2005), morphine (Kuzmin et al., 1996a, 1997), amphetamine (Cossu et al., 2001), cannabinoids (Martellotta et al., 1998a), $\gamma$-hydroxybutyric acid (Martellotta et al., 1998c; Fattore et al., 2000, 2001), scopolamine (Rasmussen and Fink-Jensen, 2000), and nicotine (Martellotta et al., 1995; Rasmussen and Swedberg, 1998; Fattore et al., 2002; Paterson et al., 2003). These studies demonstrated that drugnaive mice exhibit SA behavior similar to rats chronically trained under the same schedule of reinforcement (FR1) and using the same operant response, i.e., nose-poking (Fattore et al., 1999, 2002; Solinas et al., 2003; Spano et al., 2004; Crombag et al., 2005).

Second, we analyzed the respective roles played by the non- $\beta 2$ subunits expressed in the DAergic system, namely the $\alpha 4, \alpha 6$, and $\alpha 7$ subunits, in the modulation of acute nicotine reinforcement, and evaluated, using the lentiviral vector technology, to what extent their presence in the mesolimbic system is required for nicotine reinforcement. Acute nicotine intravenous SA was performed in drug-naive wild-type (WT) (C57BL/6J) mice, $\beta 2-\mathrm{KO}$, $\alpha 4-\mathrm{KO}, \alpha 6-\mathrm{KO}$, and $\alpha 7-\mathrm{KO}$ mice, as well as in $\mathrm{KO}$ mice with the corresponding subunit selectively re-expressed in the VTA, and $\beta 2-V E C$ mice with selective re-expression in the substantia nigra $(\mathrm{SN})$.

\section{Materials and Methods}

Subjects. Male C57BL/6J (Charles River), $\beta 2-, \alpha 4-, \alpha 6-, \alpha 7-n A C h R$ KO mice and their corresponding WT controls were used, weighing 24-28 g at the time of experiments. The animals were housed eight per cage with food and water available ad libitum, kept under standard conditions (temperature $21 \pm 1^{\circ} \mathrm{C}, 60-65 \%$ relative humidity) on reversed $12 \mathrm{~h}$ light/dark cycle (light on 7:00 P.M.) and left undisturbed for at least 10 days before starting the experimental procedure. SA sessions took place during the dark phase of the cycle, between 9:00 and 12:00 A.M. All experiments were performed in strict accordance with both the Guide for the Care and Use of Laboratory Animals (National Institutes of Health) and the E.C. regulations for animal use in research (CEE $n^{\circ}$ 86/609).

Lentiviruses. The lentiviral expression vectors are derived from the pHR' expression vectors first described by Naldini et al. (1996), with several subsequent modifications (Maskos et al., 2005). In the lentiviruses used in this study, the bicistronic expression of mouse wild-type $\beta 2$, $\alpha 4$ or $\alpha 6$ nAChR subunit cDNAs and the eGFP cDNA are under the control of the mouse phosphoglycerate kinase (PGK) promoter (see Figure $6 A$ ). The $\beta 2$ subunit expressing lentivirus is referred to as

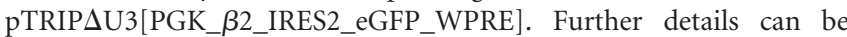
found in Maskos et al. (2005).

To create the pTRIP $\Delta$ U3[PGK_ 24 _IRES2_eGFP] construct, a three step strategy was used. First, on the expression vector containing the wild-type $\alpha 4$ cDNA, obtained from Jerry Stitzel, the NheI site located within the $\alpha 4$ cDNA was removed by mutagenesis (QuickChange, Stratagene), without affecting amino acid sequence. Second, the modified $\alpha 4$
cDNA was cloned into the pIRES2-eGFP expression plasmid (Clontech) between $\mathrm{XhoI}$ and BamHI of the multiple cloning site using a linker oligonucleotide NotI /BamHI, creating a NheI site after the $\alpha 4$ stop codon. Third, the wild-type mouse $\alpha 4$ subunit was finally ligated between the XhoI-NheI sites of the pTRIPAU3[PGK_B2_IRES2_ eGFP_WPRE] vector previously described to obtain the complete vector sequence of 13599 bp (see Fig. 6A).

To construct the pTRIP $\Delta$ U3[PGK_ $\alpha 6$ IRES2_eGFP] construct, a three-step strategy was used. First, in the expression vector containing the wild-type $\alpha 6$ cDNA plus FLAG sequence, obtained from Ines IbanezTallon, the ClaI restriction site located at the $5^{\prime}$ extremity of the $\alpha 4$ cDNA and the XhoI site in the $3^{\prime}$ extremity were replaced by mutagenesis (QuickChange, Stratagene) with XhoI and NheI, respectively. Second, another mutagenesis was performed on this modified vector to introduce a stop codon between the end of the $\alpha 6$ cDNA and the FLAG sequence. Third, the wild-type mouse $\alpha 6$ subunit cDNA was finally ligated between the XhoI-NheI sites of the pTRIPAU3[PGK_IRES2_eGFP_WPRE] vector to replace the $\beta 2 \mathrm{cDNA}$, and to obtain the complete vector sequence of 13090 bp (see Fig. 6A). All modified regions were verified by DNA sequencing.

Lentivirus stereotaxic injections. Mice aged 11-13 weeks were anesthetized using $250 \mu \mathrm{l}$ of ketamine $1.5 \%$ (Merial)/xylazine $0.05 \%$ (Bayer Healthcare) in PBS. The mouse was introduced into a stereotaxic frame adapted for use with mice (Cunningham and McKay, 1993). Lentivirus ( $2 \mu \mathrm{l}$ at $75 \mathrm{ng}$ of $\mathrm{p} 24$ protein per $\mu \mathrm{l})$ was injected bilaterally at: anteroposterior $-3.4 \mathrm{~mm}$, lateral $\pm 0.5 \mathrm{~mm}$ from bregma and $-4.4 \mathrm{~mm}$ from the surface for VTA injection. To target the SN, injections were at: antero-posterior $-3.0 \mathrm{~mm}$ (from bregma), lateral $\pm 1.3 \mathrm{~mm}$ and dorsoventral $-4.3 \mathrm{~mm}$ from the skull, as described by Avale et al. (2008). All procedures were performed in accordance with European Commission directives 219/1990 and 220/1990, and approved by Animalerie centrale and Médecine du travail, Institut Pasteur. The mice were tested after 5-6 weeks of viral expression.

Drugs. For SA experiments, (-)-nicotine bitartrate (Sigma) was freshly dissolved in $0.9 \%$ saline, and the $\mathrm{pH}$ adjusted to $7.2 \pm 0.1$ with $\mathrm{NaOH}(0.1 \mathrm{~N})$. The drug doses used in this study $(8.7,17.5,26.3,35$, and $52.6 \mu \mathrm{g} / \mathrm{kg} / \mathrm{inj}$ ) are referred to the free base, and correspond to nicotine concentrations of $0.025,0.05,0.075,0.1$ and $0.15 \mathrm{mg} / \mathrm{kg} / \mathrm{inj}$ of salt.

Self-administration procedure. Mice were tested in pairs of identical test cages $(8 \times 8 \times 8 \mathrm{~cm}$ inner size), each presenting a central frontal hole (diameter $25 \mathrm{~mm}$ ) $1 \mathrm{~cm}$ above the box floor fitted with an infrared sensor interfaced to an operating computer that controlled an automatic syringe pump (PHM-100A, Med Associates) (Fig. 1A). A rear vertical chink (5 $\mathrm{mm}$ wide) was made on the opposite wall through which the tail was extended outside the box and taped to a horizontal surface allowing access to the lateral tail veins with a $27 \mathrm{G}$ winged needle (external diameter $0.4 \mathrm{~mm}$ ), connected to the syringe through Teflon tubing.

Because mice were housed on a reversed light/dark cycle, they were kept in the dark during transportation from the housing to the experimental room. This room was always the same, exclusively dedicated to SA experiments in mice, and had the same environmental conditions as the housing room, i.e., $T=21 \pm 1^{\circ} \mathrm{C}$ and $60-65 \%$ humidity.

Self-administration sessions were conducted over several seasons, but care was taken in maintaining constant room temperature and humidity, and in ensuring that no sounds entered the experimental room. Experiments were conducted in the dark: a dim light located above the apparatus was switched on for incannulation of the tail vein only, whereas the box containing the animal was covered with black cloth so that mice were never exposed to the light. No infrared lighting or other expedients were used to provide vasodilation of the tail vein or to facilitate needle insertion. No detergents, soap or alcohol were used between sessions, distilled water only being used to clean boxes at the end of each session.

Animals were first placed in the test cage for $10 \mathrm{~min}$ of habituation (pre test) with their tails taped but no needle inserted. Pairs of animals were selected on the basis of an approximate equal level of nose-poking activity during pre test. Thereafter, the matched pairs were placed into the experimental boxes, one mouse defined as active (A) and the other one passive $(\mathrm{P})$, and needles inserted in the lateral tail vein. Animals were randomly allocated to the different experimental groups and allowed 


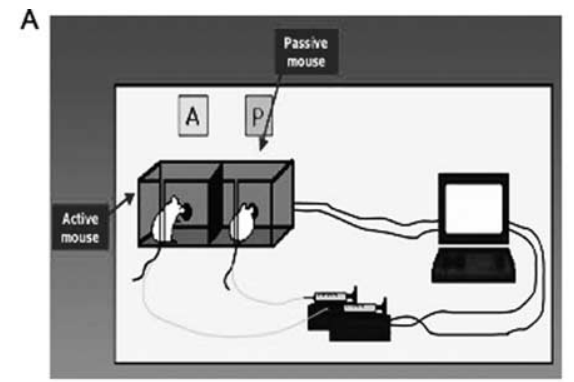

B

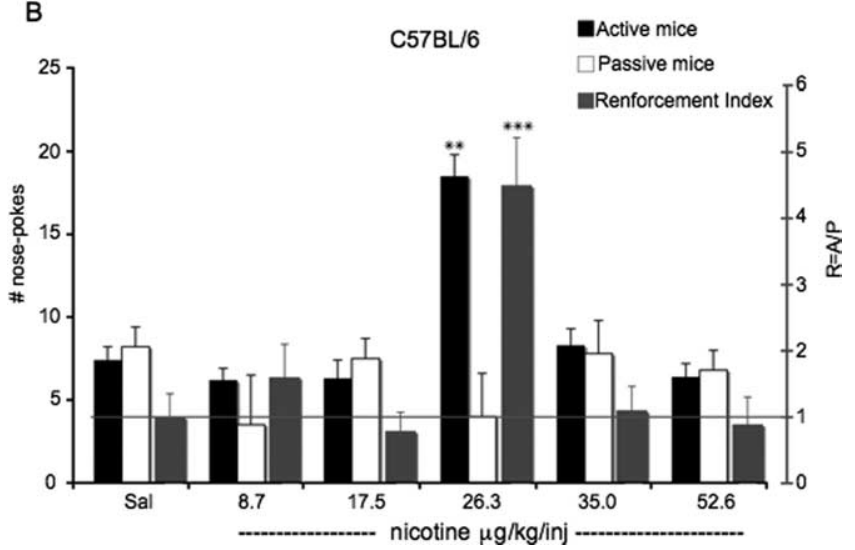

Figure 1. A, Set-up and simplified scheme for intravenous self-administration experiments. Each nose-poke of the Active (A) mouse activates a computer-operated syringe pump which delivers a nicotine injection into the tail vein of both the $A$ and the yoked Passive $(P)$ mouse. $\boldsymbol{B}$, Concentration-dependent nicotine intravenous SA in $557 \mathrm{BL} / 6$ J drug-naive mice. Each bar ( $y$ axis at left) represents the mean \pm SEM of the cumulative nose pokes (NPs) of the active mice ( $A$, black bars) and passive yoked controls ( $P$, white bars) over the 30 min session. Each gray bar ( $y$-axis at right) represents the $R$ value for mice self-administering saline (Sal) or different nicotine concentrations over the $30 \mathrm{~min}$ session. Drug doses are expressed as $\mu \mathrm{g} / \mathrm{kg} / \mathrm{infusion}$. ${ }^{* *} p<0.01$ vs yoked passive and saline groups. ANOVA followed by Dunnett's test ( $n=12-18$ pairs of animals). ${ }^{* *} p<0.001$ vs saline control group. ANOVA followed by Dunnett's test $(n=$ 12-18 pairs of animals).

access to the drug under a continuous reinforcement (FR-1) schedule. A nose-poking modus operandi was used for nicotine SA, because it reflects a more "natural" behavior for mice and requires less motor and motivational output than lever-pressing.

Each nose-poke (NP) of the active (A) mouse activated the computeroperated syringe pump delivering either nicotine or saline infusion (volume of injection: $1.0 \mu \mathrm{l}$, infusion time: $1 \mathrm{~s}$ ) both to the $\mathrm{A}$ and the passive (P) mouse, so that animals received the same amount of the drug simultaneously. A white cue light was activated by each NP of the A mouse for $1 \mathrm{~s}$, i.e., during the delivery of the drug, thus serving as a drug-associated cue along with the noise of the activated syringe pump. No cue light was activated by NPs of the yoked P mouse.

NPs of the P mouse were recorded but had no scheduled consequences. A short time-out period (i.e., inactivation of NP responses) of $2 \mathrm{~s}$ was imposed after each drug infusion. Each treatment included not $<5$ pairs of animals. SA sessions lasted $30 \mathrm{~min}$ and each mouse was used only once. The number of NPs for both animals (A and P mice) in each treatment group was analyzed with two-way ANOVA to evaluate effects of drug delivery mode ("contingently" versus "noncontingently"), unit dose (including vehicle), and interactions between group and drug dose. For post hoc comparisons, Dunnett's test was used to compare single groups of mice, and respective vehicle controls. Statistical significance was set at $p<0.05$. The whole study was designed as a between-subjects (independent groups) experiment, because each treatment we describe was performed on a single set of animals.

To obtain gradual measurements of the reinforcing effects of nicotine, the mean ratio (or Reinforcement Index) R (Kuzmin et al., 1996a,b; Martellotta et al., 1998a,b) between the number of responses (NPs) of the active (A) and passive (P) mice during the 30 min session was calculated, nicotine effect being considered rewarding, neutral or aversive when $\mathrm{R}$ was greater than, equal to, or $<1$, respectively.

Receptor autoradiography. Brains from WT, $\beta 2-\mathrm{KO}, \alpha 4-\mathrm{KO}, \alpha 6-\mathrm{KO}$, and re-injected mice were dissected, frozen in dry ice, and stored at $-80^{\circ} \mathrm{C}$ until use. Twenty-micrometer-thick coronal sections were obtained by on a cryostat at $-20^{\circ} \mathrm{C}$, and thaw mounted on Menzel Gläser SuperFrost Plus microscope slides. Sections were kept at $-80^{\circ} \mathrm{C}$ until the binding assay. Sections used for $\left[{ }^{125} \mathrm{I}\right]$ epibatidine binding were incubated at room temperature with $200 \mathrm{pm}\left[{ }^{125} \mathrm{I}\right]$ epibatidine (NEN PerkinElmer; specific activity $2200 \mathrm{Ci} / \mathrm{mmol}$ ) in Tris $50 \mathrm{~mm} \mathrm{pH} 7.4$ for $1 \mathrm{~h}$. Then, sections were rinsed twice in the same buffer for $5 \mathrm{~min}$, once briefly in distilled water, and exposed to film. Details of the procedure were described previously (Zoli et al., 1998).

The $\left[{ }^{125} \mathrm{I}\right]$ conotoxin MII binding procedure was adapted from Whiteaker et al. (2000). Sections were preincubated in binding buffer $(144 \mathrm{mM}$ $\mathrm{NaCl}, 1.5 \mathrm{~mm} \mathrm{KCl}, 2 \mathrm{~mm} \mathrm{CaCl}_{2}, 1 \mathrm{~mm} \mathrm{MgSO}_{4}, 20$ mм HEPES, 0.1\% BSA, $\mathrm{pH}$ 6.8) $+1 \mathrm{~mm}$ PMSF at $25^{\circ} \mathrm{C}$ for $15 \mathrm{~min}$. Binding reaction was performed in binding buffer supplemented with $0.1 \%$ BSA, 5 mm EDTA, 5 mM EGTA, and $10 \mu \mathrm{g} / \mathrm{ml}$ aprotinin, leupeptin and pepstatin. The sections were incubated at $25^{\circ} \mathrm{C}$ for $2 \mathrm{~h}$ with $0.5 \mathrm{~nm}\left[{ }^{125} \mathrm{I}\right]$ conotoxin MII. Then, sections were rinsed for $30 \mathrm{~s}$ once in binding buffer at $25^{\circ} \mathrm{C}$, twice in binding buffer at $4^{\circ} \mathrm{C}$, twice in binding buffer diluted $1 / 10$ at $4^{\circ} \mathrm{C}$, and finally once in $5 \mathrm{~mm}$ HEPES at $4^{\circ} \mathrm{C}$. The slides were dried on a slide drying bench before being exposed for $24 \mathrm{~h}$ to Kodak Biomax MS films with appropriate ${ }^{125}$ I standards.

\section{Results}

Nicotine dose-response curve in C57BL/6J drug-naive mice The mouse model for acute intravenous SA in drug-naive animals is schematically presented in Figure $1 A$. Both the "active" (A) and the "passive" (P) mouse are in neighboring cages, cannulated in the tail vein, and exposed to the same amount of nicotine at the same time, determined by the nose-poke behavior of the A mouse. The procedure was first validated using saline and nicotine in $\mathrm{C} 57 \mathrm{BL} / 6 \mathrm{~J}$ mice, which represents the background strain of WT and KO mice used in this study. The data are presented both in terms of the number of nose pokes (NP) of the A and $\mathrm{P}$ mouse, and their ratio, the Reinforcement Index, R, see Materials and Methods.

As shown in Figure $1 B$, an $\mathrm{R}$ value close to 1 implied no statistically significant difference in the mean number of responses of A and P C57BL/6J mice when saline (Sal) was made available (red bar). Conversely, a nicotine concentration of 26.3 $\mu \mathrm{g}$ per $\mathrm{kg}$ and per infusion $(\mu \mathrm{g} / \mathrm{kg} / \mathrm{inf})$ significantly increased responding in the active mice $(18.5 \pm 1.3)$, although not affecting nose-poking activity of yoked passive animals $(4.2 \pm 2.6)$, so that resulting $\mathrm{R}$ values were $>1$ (red bar). By increasing the $\mathrm{R}$ value above unity, the nicotine concentration of $26.3 \mu \mathrm{g} / \mathrm{kg} / \mathrm{inf}$ is considered to possess reinforcing properties. ANOVA analysis confirmed highly significant differences in nose-poking activity among experimental groups $\left(F_{(7,107)}=26.31, p<0.01\right)$. Conversely, no differences were obtained between active and passive mice at nicotine concentrations of $8.7,17.5,35$ and $52.6 \mu \mathrm{g} / \mathrm{kg} /$ inf, with $\mathrm{R}$ values being close to 1 .

This experiment demonstrated that nicotine exerts a positive reinforcing effect in C57BL/6J drug-naive mice following a dosedependent U-shaped curve, as already reported for nicotine in DBA mice (Fattore et al., 2002), and for other drugs of abuse (Martellotta et al., 1998a,b; Ledent et al., 1999; Fattore et al., 2000; Cossu et al., 2001), under the same experimental conditions.

\section{Absence of nicotine intravenous SA in $\beta 2-n A C h R ~ K O$ drug-naive mice}

Figure $2 A$ illustrates nicotine intravenous SA in mice lacking the $\beta 2$ subunit of the $\mathrm{nAChR}(\beta 2-\mathrm{KO}$ mice). It can be noted that 
A

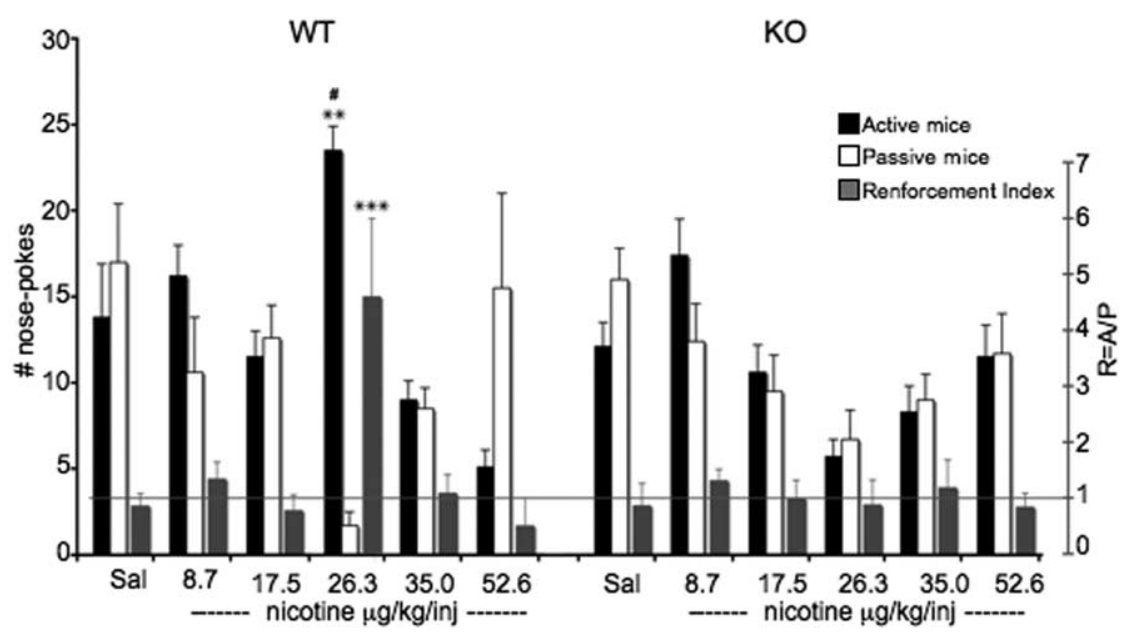

B

\section{$\beta 2$-VEC-VTA}

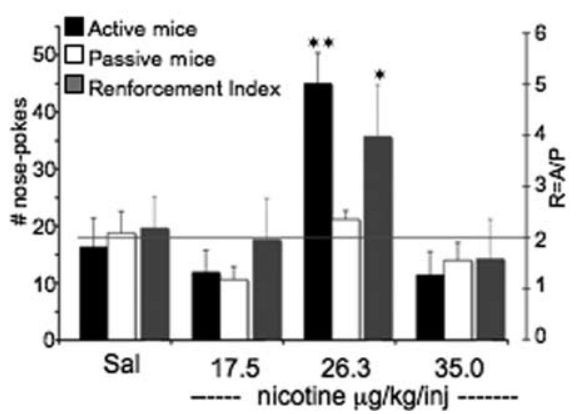

$\beta 2$

c

Figure 2. $\quad \boldsymbol{A}$, Nicotine intravenous SA in $\beta 2$-nAChR knock-out (KO) and wild-type (WT) mice. Each bar ( $y$-axis at left) represents the mean \pm SEM of the cumulative nose pokes (NPs) of the $\beta 2$-WT (left) and $\beta 2$-KO (right) active mice (A, black bars) and passive yoked controls ( $P$, white bars) over the 30 min session. Each gray bar ( $y$-axis at right) represents the $R$ value for $\beta 2$-WT (left) and $\beta 2$-KO (right) mice self-administering nicotine over the 30 min session. Doses are expressed as $\mu \mathrm{g} / \mathrm{kg} / \mathrm{inf}$. " $p<0.05$ vs corresponding saline group and ${ }^{* *} p<0.01$ vs corresponding yoked passive group. ANOVA followed by Dunnett's test $(n=7-13$ pairs of animals). ${ }^{* *} p<0.001$ vs corresponding saline group. ANOVA followed by Dunnett's test ( $n=7-13$ pairs of animals). $\boldsymbol{B}$, Nicotine intravenous SA in ventral tegmental area (VTA) re-expressed $\beta 2$-KO mice ( $\beta 2$-VEC-VTA mice). Each bar ( $y$-axis at left) represents the mean \pm SEM of the cumulative nose pokes (NPS) of the $\beta 2$-VEC-VTA active mice (A, black bars) and passive yoked controls ( $P$, white bars) over the 30 min session. Each gray bar ( $y$-axis at right) represents the $R$ value for $\beta 2-V E C-V T A$ mice self-administering saline (Sal) or nicotine over the $30 \mathrm{~min}$ session. Doses are expressed as $\mu \mathrm{g} / \mathrm{kg} / \mathrm{inf} .{ }^{* *} p<0.01$ vs yoked passive mice and saline controls. ANOVA followed by Dunnett's test ( $n=6-8$ pairs of animals). ${ }^{*} p<0.05$ vs saline control group. ANOVA followed by Dunnett's test ( $n=6-8$ pairs of animals). C, Nicotine intravenous SA in substantia nigra (SN) re-expressed $\beta 2-K 0$ mice ( $\beta 2$-VEC-SN mice). Each bar ( $y$-axis at left) represents the mean \pm SEM of the cumulative nose pokes (NPS) of the $\beta 2$-VEC-SN active mice (A, black bars) and passive yoked controls ( $P$, white bars) over the 30 min session ( $n=6-14$ pairs of animals). Each gray bar ( $y$-axis at right) represents the R value for $\beta 2$-VEC-SN mice self-administering saline (Sal) or nicotine over the 30 min session. Doses are expressed as $\mu \mathrm{g} / \mathrm{kg} / \mathrm{inf}$ ( $n=6-14$ pairs of animals).

when saline infusions (Sal) were made contingent on nosepoking activity, the $\mathrm{R}$ value was close to 1 , indicating no statistically significant difference in the mean number of NPs between active and passive $\beta 2-\mathrm{KO}$ mice (Fig. $2 A$, right). Yet, unlike C57BL/6J mice (Fig. $1 B$ ) and WT mice (Fig. $2 A$, left), active $\beta 2-\mathrm{KO}$ animals to which free access to nicotine was given at the dose of $26.3 \mu \mathrm{g} / \mathrm{kg} / \mathrm{inf}$ did not increase their rate of responding with respect to either passive animals receiving noncontingent nicotine infusions or control animals receiving contingent vehicle (saline) infusions $\left(F_{(3,29)}=1.39, \mathrm{~ns}\right)$. All of the doses tested were ineffective in inducing nicotine SA behavior in $\beta 2-\mathrm{KO}$ mice, so that the reinforcement index (R) was equivalent to 1 (Fig. $2 \mathrm{~A}$, right).

\section{Recovery of nicotine intravenous SA} after re-expression of $\beta 2$ in the VTA but not the $\mathrm{SN}$ of $\boldsymbol{\beta} 2-\mathrm{KO}$ mice

As shown in Figure $2 B$, when saline was made contingent on NP responses of VTA re-expressed $\beta 2-\mathrm{KO}$ mice $(\beta 2-V E C$ $V T A$ ), active and passive animals displayed a similar mean number of responses, as indicated by the $\mathrm{R}$ value (gray bar). However, when mice were allowed to intravenously self-administer nicotine at $26.3 \mu \mathrm{g} / \mathrm{kg} / \mathrm{inf}$ (black bars), active mice significantly increased their rate of nosepoking activity with respect to both yoked passive mice (white bars) receiving nicotine noncontingently, and control mice receiving saline (Sal). Accordingly, the nicotine concentration of $26.3 \mu \mathrm{g} / \mathrm{kg} / \mathrm{inf}$ increased R above unity (gray bar), and an overall significant effect of drug was revealed by post hoc comparisons $\left(F_{(3,21)}=\right.$ $10.74, p<0.01$ ). Nicotine thus exerts positive reinforcing effects in VTA reexpressed $\beta 2$-KO mice, where it is able to sustain acute SA behavior.

In another set of mice, the $\beta 2$ subunit was selectively re-expressed in the substantia nigra $(\beta 2-V E C-S N)$ and the mice tested under the same conditions. As shown in Figure $2 C$, nicotine at $26.3 \mu \mathrm{g} /$ $\mathrm{kg} / \mathrm{inf}$ did not modify the $\mathrm{R}$ index (gray bar) with respect to saline (Sal), thus showing no intravenous nicotine SA at this unit nicotine dose. Lower and higher concentrations of 17.5 and $35 \mu \mathrm{g} / \mathrm{kg} / \mathrm{inf}$, respectively, did not result in nicotine SA as well, thus proving absence of any shift in the dose-response curve. Nicotine thus exerts positive reinforcing effects only when the $\beta 2$-subunit is re-expressed in the VTA, but not in the SN.

\section{Identifying the role played by} homomeric $\alpha 7^{\star}$-nAChRs in the VTA The $\alpha 7^{\star}$-nAChRs in the VTA have been described to modulate the discharge pattern of DA neurons (Mameli-Engvall et al., 2006) and to mediate long-term effects of chronic exposure to nicotine (Besson et al., 2007). McGehee and Mansvelder had also established their importance for nicotine induced LTP in the VTA (Mansvelder and McGehee, 2000; Mansvelder et al., 2002).

Their role was thus tested in acute nicotine SA. As shown in Figure 3, we found that, as in the $\beta 2-\mathrm{WT}$ and VTA-VEC mice, the only effective dose of nicotine in sustaining SA behavior was 26.3 $\mu \mathrm{g} / \mathrm{kg} / \mathrm{inf}$, the only nicotine concentration significantly increasing $\mathrm{R}>1$ (gray bar). Under these conditions, both $\alpha 7$-WT (left) and $\alpha 7-\mathrm{KO}$ (right) active mice (black bars) displayed a robust increase in NP numbers over saline (Sal) controls and over the corresponding passive mice (white bars), thus showing that the lack of $\alpha 7$-subunit does not interfere with the acute rewarding effects of nicotine. 


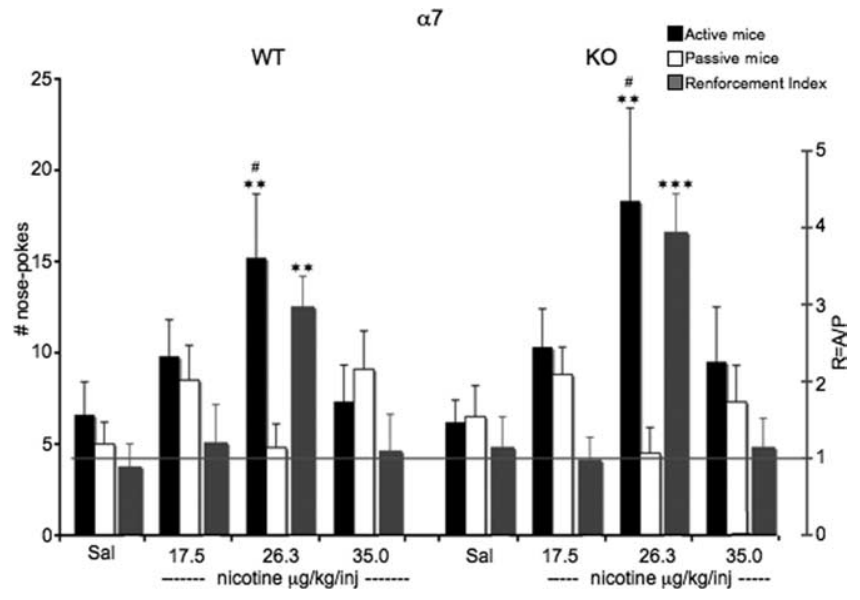

Figure 3. Nicotine intravenous SA in $\alpha 7-n A C h R ~ K 0$ and WT mice. Each bar ( $y$-axis at left) represents the mean \pm SEM of the cumulative nose pokes (NPs) of the $\alpha 7$-WT (left) and $\alpha 7$-K0 (right) active mice ( $A$, black bars) and passive yoked controls ( $P$, white bars) over the 30 min session. Each gray bar ( $y$-axis at right) represents the R value for $\alpha 7$-WT (left) and $\alpha 7-K 0$ (right) mice self-administering saline (Sal) or nicotine over the 30 min session. Doses are expressed as $\mu \mathrm{g} / \mathrm{kg} /$ inf. $^{\#} p<0.05$ vs corresponding saline group and ${ }^{* *} p<0.01$ vs corresponding yoked passive group. ANOVA followed by Dunnett's test ( $n=6-8$ pairs of animals). ${ }^{* *} p<$ 0.01 and $^{* * *} p<0.001$ vs corresponding saline group. ANOVA followed by Dunnett's test $(n=$ $6-8$ pairs of animals).

\section{The role played by the $\alpha 4$ subunit partner of $\beta 2$ in the VTA}

The $\alpha 4$ subunit is among the main partners of the $\beta 2$ subunit, coexpressed in DAergic and GABAergic neurons of the VTA (Klink et al., 2001; Champtiaux et al., 2002, 2003). Mice deleted for the $\alpha 4$ subunit and their corresponding WT littermates were therefore tested for nicotine reinforcement at the same doses as for the $\beta 2$-KO mice. As shown in Figure $4 A, \alpha 4$-WT mice (left) exhibited a U-shaped dose-response curve for nicotine. Yet, as for $\beta 2-\mathrm{KO}$ animals, $\alpha 4-\mathrm{KO}$ animals (right) did not reveal $\mathrm{R}$ values significantly different from 1 (gray bars), showing the absence of nicotine reinforcement at all of the doses tested.

A lentivirus was then constructed expressing the $\alpha 4$-subunit (see Fig. 6A). As shown in Figure $4 B$, nicotine reinforcement was promptly restored by selective re-expression of the $\alpha 4$ subunit in the VTA, a nicotine concentration of $26.3 \mu \mathrm{g} / \mathrm{kg} / \mathrm{inf}$ being able to increase the $\mathrm{R}$ value $>1$ (gray bar). Along with previous results from experiments with $\beta 2$-VEC-VTA mice, these data highlight the critical role played by the $\alpha 4 \beta 2^{\star}$ containing subtype of $n A C h R s$ in mediating the acute reinforcing properties of nicotine.

\section{The role played by the $\alpha 6$ subunit in the VTA}

This subunit has generated substantial interest since its original description because of its differential expression in the DAergic system, and its role in locomotion (Le Novère et al., 1996, 1999). Yet, $\alpha 6-\mathrm{KO}$ animals did not show any overt developmental, neurological or behavioral deficits (Champtiaux et al., 2002, 2003). However, when tested in our SA paradigm, although $\alpha 6-\mathrm{WT}$ animals (left) did self-administer nicotine at the unit dose of 26.3 $\mu \mathrm{g} / \mathrm{kg} / \mathrm{inf}, \alpha 6-\mathrm{KO}$ drug-naive mice (right) did not do so, as illustrated in Figure $5 A$. The $\alpha 6-\mathrm{KO}$ did not self-administer nicotine even within an extensive range of lower $(8.7-17.5 \mu \mathrm{g} / \mathrm{kg} / \mathrm{inf})$ or higher (35-52.6 $\mu \mathrm{g} / \mathrm{kg} / \mathrm{inf})$ doses, showing $\mathrm{R}$ values close to 1 (gray bars). This finding provides the first behavioral phenotypes identified so far in the $\alpha 6-\mathrm{KO}$ line.

The $\alpha 6$ subunit was then selectively re-expressed using a lentiviral vector (Fig. 6A) in the VTA of $\alpha 6-\mathrm{KO}$ mice (Fig. $6 B$ ) and the mice tested under the same conditions. Active mice (black bars) significantly $(p<0.01)$ increased their rate of nose-poking for nicotine at $26.3 \mu \mathrm{g} / \mathrm{kg} / \mathrm{inf}$ with respect to their yoked passive mice (white bars), and the $\mathrm{R}$ value was therefore $>1$, as indicated in Figure $5 B$ (gray bars). Conversely, active and passive $\alpha 6-V E C$ $V T A$ mice displayed a similar mean number of responses when either saline (Sal) or nicotine at 17.5 and $35 \mu \mathrm{g} / \mathrm{kg} / \mathrm{inf}$ were made contingent on NP responses. Nicotine thus exerts positive reinforcing effects in VTA re-expressed $\alpha 6$-KO mice, where it is able to sustain acute SA behavior. This experiment demonstrates that $\alpha 6 \beta 2^{\star} \mathrm{nAChRs}$ in the VTA and/or in its projections are necessary and sufficient to establish nicotine SA behavior.

\section{Verifying the injection sites in VEC mice}

Figure $6 B$ illustrates representative samples of specific ligand binding experiments performed on WT, KO and VEC mice, covering the different genotypes and injection paradigms. In the upper part of the figure, binding of iodinated epibatidine reveals the lack of high affinity binding sites in $\beta 2$ and $\alpha 4 \mathrm{KO}$ mice, whereas these are restored in the corresponding vectorised mice. As shown before for $\beta 2$ injection into the SN (Avale et al., 2008), $\beta 2$ re-expression in the $\mathrm{SN}$ yields a strong signal in the area of the $\mathrm{SN}$ pars compacta, sparing the VTA.

In the lower part, binding of iodinated conotoxin MII was performed to identify $\alpha 6^{\star}$-nAChRs. In $\alpha 6-\mathrm{KO}$ mice no specific signal was obtained in the VTA, whereas a strong signal was visible in WT mice, and in VEC mice.

\section{Discussion}

We have developed a robust, reproducible method for intravenous nicotine self-administration in drug-naive mice and applied it to a detailed study of the role of homo- and heteropentameric $\mathrm{nAChRs}$ in this acute paradigm. The method is robust because it was performed in different seasons, over a couple of years, and yielded reproducible results as demonstrated by the comparable data obtained with WT mice of the different KO strains. In the Materials and Methods section we have identified key issues required, like a reversed light/dark cycle, carrying out experiments in the dark, and "nose-poking" rather than "lever-pressing" as modus operandi. Because lever-pressing activity requires more motor and motivational output than nose-poking, it likely may prove to be a less "natural" behavior for mice, and therefore not be the most suitable to unmask behavioral differences in drugtaking behavior.

Our work demonstrates first of all that, in line with previous studies, drug-naive C57BL/6J mice are sensitive to nicotine's reinforcing effects (Robinson et al., 1996; Stolerman et al., 1999). They display a typical inverted U-shaped dose-response curve to intravenous nicotine, as observed in two previous studies (Fattore et al., 2002; Paterson et al., 2003). Moreover, in agreement with the data of Paterson et al. (2003), a sharp dose-response curve was obtained, and a dose of $26.3 \mu \mathrm{g} / \mathrm{kg} / \mathrm{inf}$ was confirmed as being the only reinforcing one in sustaining acute SA behavior (Rasmussen and Swedberg, 1998). These findings, that only one specific dose of nicotine is able to sustain SA behavior, are reminiscent of human studies in which adult smokers clearly titrate their nicotine intake carefully to experience the positive effects of the drug (Benowitz and Jacob, 1985; Benowitz, 2001). Similarly, adolescent smokers do titrate their nicotine intake in response to smoking low yield cigarettes by taking more puffs per cigarette (Kassel et al., 2007).

Also in line with previous studies, $\beta 2-\mathrm{KO}$ mice no longer self-administer nicotine intravenously (Picciotto et al., 1998), or 
A

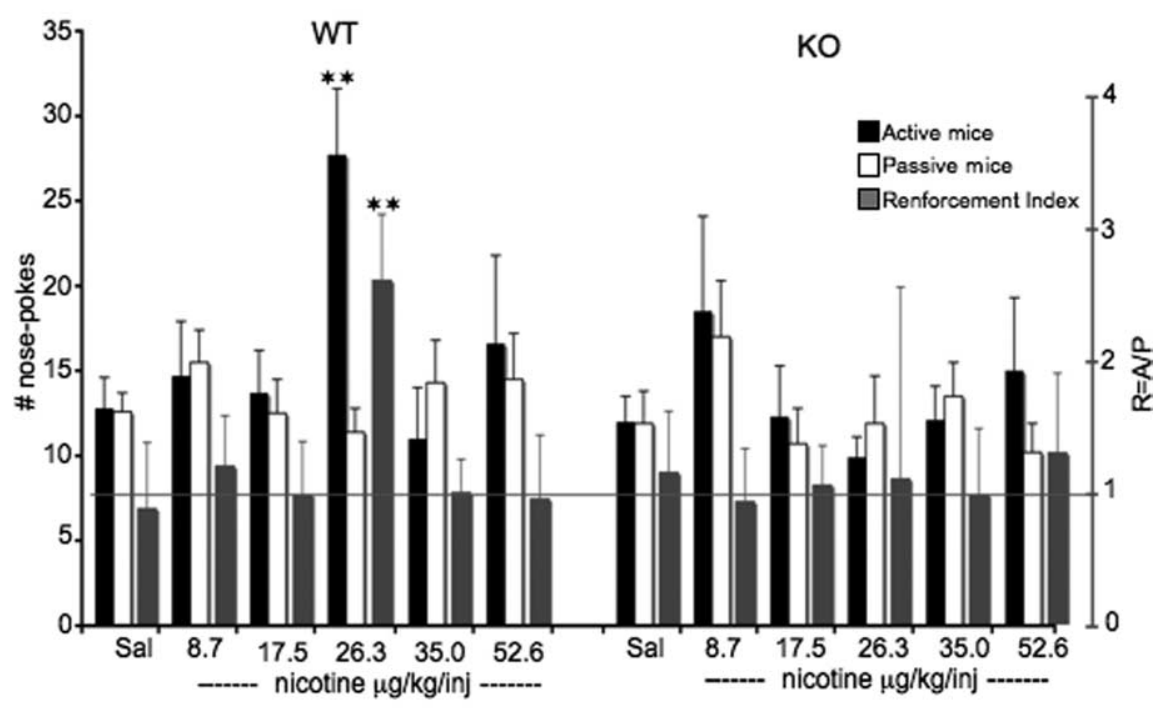

B

\section{$\alpha 4-V E C-V T A$}

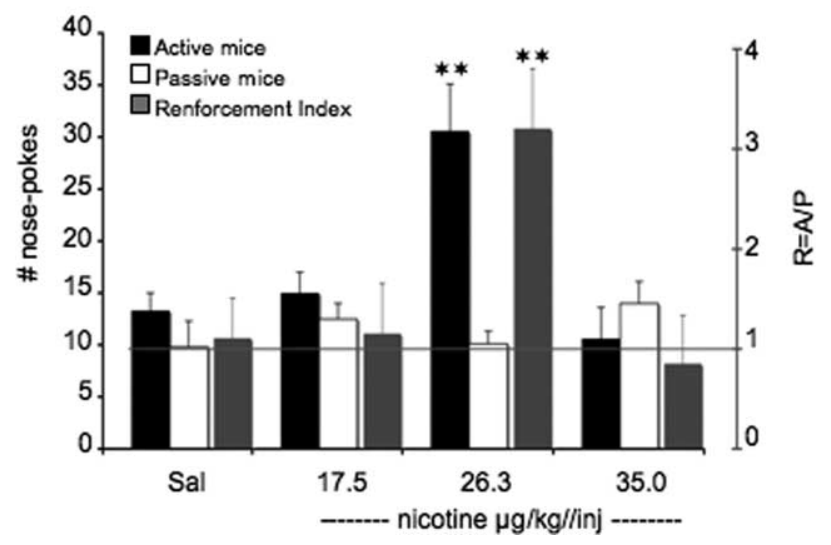

Figure 4. A, Nicotine intravenous SA in $\alpha 4$-nAChR K0 and WT mice. Each bar ( $y$-axis at left) represents the mean \pm SEM of the cumulative nose pokes (NPs) of the $\alpha 4$-WT (left) and $\alpha 4$-KO (right) active mice (A, black bars) and passiveyoked controls (P, white bars) over the 30 min session. Each gray bar represents R value for $\alpha 4$-WT (left) and $\alpha 4$-KO (right) mice self-administering saline (Sal) nicotine over the $30 \mathrm{~min}$ session. Doses are expressed as $\mu \mathrm{g} / \mathrm{kg} / \mathrm{inf} .{ }^{* *} p<0.01$ vs corresponding yoked passive and $/$ or saline groups. ANOVA followed by Dunnett's test ( $n=5-14$ pairs of animals). ${ }^{* *} p<0.01$ vs corresponding saline group. ANOVA followed by Dunnett's test ( $n=5-14$ pairs of animals). $B$, Nicotine intravenous SA in VTA re-expressed $\alpha 4$-K0 mice ( $\alpha 4$-VEC-VTA mice). Each bar ( $y$-axis at left) represents the mean \pm SEM of the cumulative nose pokes (NPs) of the $\alpha 4$-VEC-VTA active mice (A, black bars) and passive yoked controls ( $P$, white bars) over the 30 min session. Each gray bar ( $y$-axis at right) represents the R value for $\alpha 4$-VEC-VTA mice self-administering saline (white bar) or nicotine (black bars) over the 30 min session. Doses are expressed as $\mu \mathrm{g} / \mathrm{kg} / \mathrm{inf} .{ }^{* *} p<0.01$ vs corresponding saline group. ANOVA followed by Dunnett's test $\left(n=6-10\right.$ pairs of animals). ${ }^{* *} p<$ 0.01 vs saline control group. ANOVA followed by Dunnett's test ( $n=6-10$ pairs of animals).

into the VTA (Maskos et al., 2005). In addition, the data obtained with $\beta 2-V E C-V T A$ mice are consistent with the observation that nicotine increases the burst firing of VTA DAergic neurons (Grenhoff et al., 1986; Mameli-Engvall et al., 2006), decreases electrical self-stimulation in the VTA (Ivanova and Greenshaw, 1997), and dose-dependently enhances DA release when perfused into the VTA (Tizabi et al., 2002; Rahman et al., 2004). Accordingly, infusion of nicotinic antagonist into the VTA significantly decreases nicotine SA in the rat (Corrigall et al., 1994).

Moreover, re-expression of the $\beta 2$ subunit in the $\mathrm{SN}$ pars compacta (Avale et al., 2008) instead of the VTA of $\beta 2-\mathrm{KO}$ mice did not yield any nicotine SA. The present study thus unequivocally identifies the presence of the $\mathrm{nAChR} \beta 2$ subunit in the VTA as the critical condition for nicotine intravenous SA in drug-naive animals. Consistent with this conclusion, nicotine SA is altered by lesions of the posterior portion of the pedunculopontine tegmental nucleus, which innervates VTA DAergic neurons, but not by lesions of the anterior region projecting to $\mathrm{SN}$ pars compacta (Alderson et al., 2006). Yet, additional brain structures such as the central linear nucleus raphé, located posterodorsally to the VTA, and the supramammilary nucleus of the posterior hypothalamus, located anterior to the VTA, may also contribute to the primary reinforcing effects of nicotine, at least in the rat (Ikemoto et al., 2006). Findings from the present study also demonstrate that drug-naive $\alpha 7-\mathrm{KO}$ mice do self-administer nicotine in a manner indistinguishable from their WT counterparts. This finding is consistent with the pharmacological evidence that the $\alpha 7$ subunit is not involved in chronic nicotine SA in trained rats (Grottick et al., 2000), nor in nicotine-induced conditioned place preference (Walters et al., 2006). Recent work (Besson et al., 2007; Salas et al., 2007) suggests that $\alpha 7^{*}$ nAChRs play a key role in long-term adaptations to passive chronic nicotine, rather than in the short-term response to nicotine SA.

These in vivo data also invite comparison with the work of McGehee and Mansvelder performed in slices (Mansvelder and McGehee, 2000; Mansvelder et al., 2002). They could show that short application of nicotine leads to the desensitization of heteromeric receptors on both the GABAergic and DAergic neurons in the VTA. Because $\alpha 7^{*}$-nAChRs on glutamatergic axons in the VTA do not desensitize, the net effect is an increased glutamatergic stimulation of the DA neurons in the VTA, explaining the increase in DA cell firing. This increase in elicited DA release is then considered the key step in nicotine reinforcement. It is difficult here to extrapolate from these in vitro studies to our acute reinforcement paradigm. In slices, important afferents, like the cholinergic input from the mesopontine tegmentum, as discussed above (Alderson et al., 2006), get severed. Our in vivo work suggests that this $\alpha 7^{\star}$-nAChR mediated effect is not crucial for nicotine SA in an acute paradigm, and we also been able to establish recently that $\alpha 7$-KO mice exhibit only a slightly altered electrophysiological response to nicotine injection when DAergic neurons are recorded in vivo (Mameli-Engvall et al., 2006).

The $\alpha 4$ subunit partner of the $\beta 2$ subunit has also been implicated in reward: selective activation of $\alpha 4^{\star}-\mathrm{nAChRs}$ by low doses of nicotine that do not activate other $\mathrm{nAChR}$ subtypes has been reported to be sufficient for nicotine-induced reward, as tested by conditioned place preference (Tapper et al., 2004). Consistent 
with this view, $\alpha 4-\mathrm{KO}$ mice did not show significant nicotine SA and this behavior was promptly restored only after the targeted re-expression of the $\alpha 4$ subunit in the VTA. $\alpha 4 \beta 2^{\star}$-nAChRs are thus major players in acute nicotine SA in drug-naive mice.

A rather surprising result of our study is the loss of nicotine SA in $\alpha 6-\mathrm{KO}$ mice. The $\alpha 6$ subunit is to a large extent coexpressed with the $\alpha 4$ subunit in DAergic neurons of the VTA. $\alpha 4 \beta 2^{\star}-, \alpha 6 \beta 2^{\star}$-, and $\alpha 4 \alpha 6 \beta 2^{\star}$ $\mathrm{nAChRs}$ have been found enriched in the terminal fields of these neurons in the $\mathrm{Nu}$ cleus accumbens (NuAcc) (Champtiaux et al., 2003; Salminen et al., 2007). We thus demonstrate that $\alpha 6^{\star}-\mathrm{nAChRs}$ cannot compensate for the absence of the $\alpha 4$ subunit, and vice versa, although both are widely expressed in VTA neurons. Importantly, targeted re-expression of the $\alpha 6$ subunit in the VTA of $\alpha 6-\mathrm{KO}$ mice promptly restored nicotine SA behavior, confirming the VTA as the key area in mediating nicotine reinforcement.

Our in vivo findings can be seen as a behavioral correlate of recent in vitro work using fast-scan cyclic voltammetry in slices of mouse NuAcc (Exley et al., 2008). This study indeed showed that $\alpha$-conotoxin MII, a specific antagonist of $\alpha 6^{*}$-nAChRs, selectively suppressed DA release evoked by single and low-frequency action potentials, whereas DA release was potently enhanced by high-frequency bursts. This filtering effect, previously described for nicotine (Rice and Cragg, 2004; Zhang and Sulzer, 2004), is considered the key event in the establishment of saliency of nicotine-associated cues. In this paradigm, $\alpha 6^{*}$-nAChRs therefore dominate the control of DA neurotransmission, when nicotine is applied to the slice. Our in vivo results on $\alpha 4-\mathrm{KO}$ and $\alpha 6-\mathrm{KO}$ mice together with the in vitro study of Exley et al. (2008) thus highlight the crucial role of $\alpha 4^{*}$ and $\alpha 6^{\star}$-nAChRs in nicotine reinforcement.

Our re-expression technique targets both DA and GABAergic neurons in the VTA (Maskos et al., 2005), such that both transmitter systems have their nAChRs restored in the VEC mice. Thus the questions remains as to the relative importance of nAChRs in GABA vs DA neurons for the SA behavior measured here. McGehee and Mansvelder have shown that heteromeric nicotinic receptors play a role in both neurotransmitters systems of the VTA (Mansvelder and McGehee, 2000; Mansvelder et al., 2002) for the increase in DA cell firing, and consequently DA release, considered the key step in the reinforcing effects of a drug. It would thus be interesting to further dissect the action of nicotine in the VTA with respect to neurotransmitter subtype. This issue can be addressed by the selective targeting of nAChRs to GABAergic and DA cells using lentiviral vectors with specific promoters. This work is currently under way (Tolu et al., 2007).

B
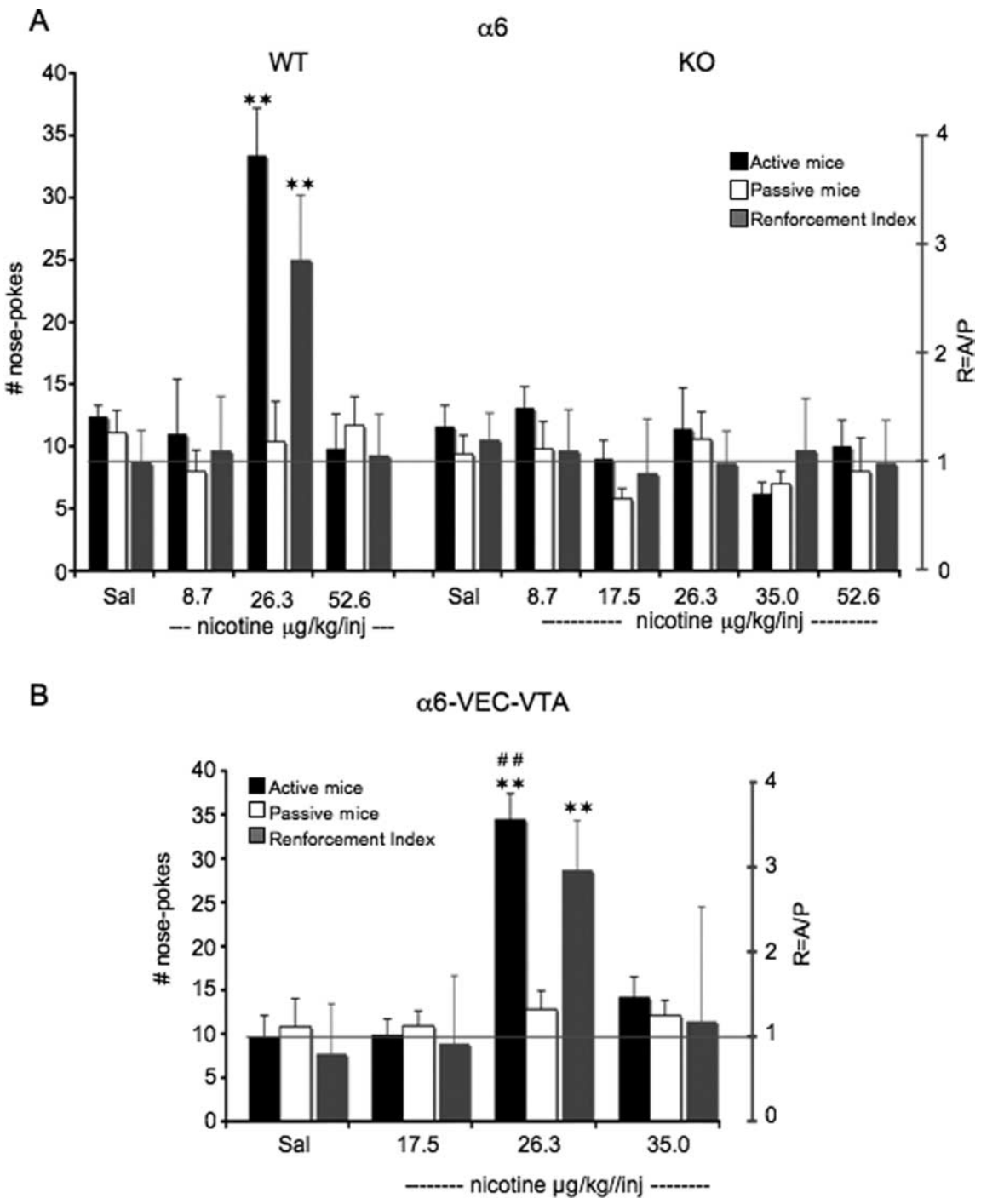

Figure 5. A, Nicotine intravenous SA in $\alpha 6$-nAChR K0 and WT mice. Each bar ( $y$-axis at left) represents the mean \pm SEM of the cumulative nose pokes (NPs) of the $\alpha 6$-WT (left) and $\alpha 6$-KO (right) active mice (A, black bars) and passive yoked controls (P, white bars) over the 30 min session. Each gray bar ( $y$-axis at right) represents the R value for $\alpha 6$-WT (left) and $\alpha 6$-K0 (right) mice self-administering saline (Sal) or nicotine over the 30 min session. Doses are expressed as $\mu \mathrm{g} / \mathrm{kg} / \mathrm{inf} .{ }^{\#} p<0.05$ vs corresponding saline group and ${ }^{* *} p<0.01$ vs corresponding yoked passive or saline control groups. ANOVA followed by Dunnett's test ( $n=$ $6-8$ pairs of animals). ${ }^{* *} p<0.01$ vs corresponding saline group. ANOVA followed by Dunnett's test ( $n=6-8$ pairs of animals). $B$, Nicotine intravenous SA in VTA re-expressed $\alpha 6$-K0 mice ( $\alpha 6$-VEC-VTA mice). Each bar ( $y$-axis at left) represents the mean \pm he 30 min session. Doses are expressed as $\mu \mathrm{g} / \mathrm{kg} / \mathrm{inf} .{ }^{\# \#} p<0.001$ vs corresponding saline group and ${ }^{* *} p<0.01$ vs corresponding yoked passive or saline control groups. ANOVA followed by Dunnett's test ( $n=9-11$ pairs of animals). ${ }^{* *} p<0.01$ vs saline controls. ANOVA followed by Dunnett's test ( $n=9-11$ pairs of animals).

In conclusion, we have demonstrated that the presence of the $\beta 2, \alpha 4$, and $\alpha 6$ subunits in cell bodies of the VTA and their corresponding mesolimbic terminals is necessary and sufficient for acute intravenous SA of a pharmacological dose of nicotine. It is thus tempting to speculate that a specific $\alpha 4 \alpha 6 \beta 2^{\star}-\mathrm{nAChR}$ is the key mediator of intravenous SA. This hypothesis can be tested once FRET experiments using tagged nicotinic subunits will become possible in vivo (Nashmi et al., 2003; Drenan et al., 2008), to prove the presence and identify the functional properties of a given subunit combination.

On the contrary, the $\alpha 7$ subunit is not involved in mediating the acute reinforcing properties of nicotine. These findings illustrate the 
A

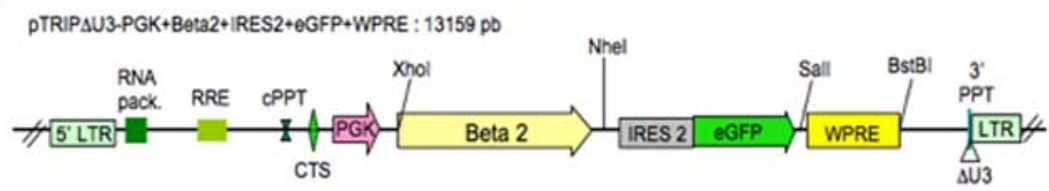

PTRIPAU3-PGK+ANDQ4+IRES2+eGFP+WPRE : 13599 pD

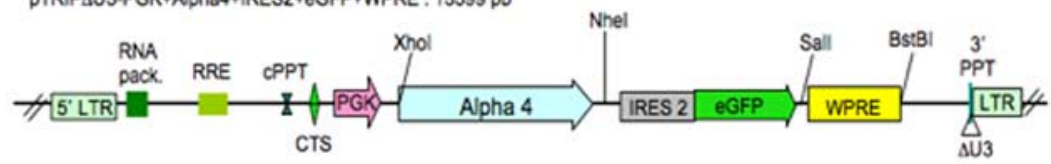

PTRIPAU3-PGK+ANha6+iRES2+eGFP+WPRE : 13090 pb

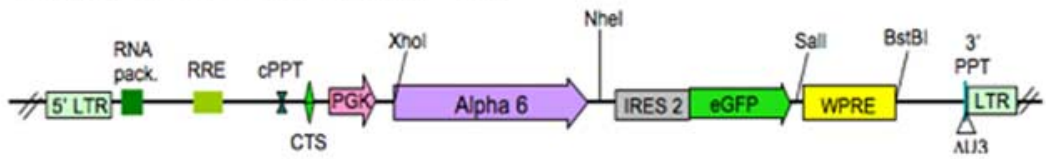

B

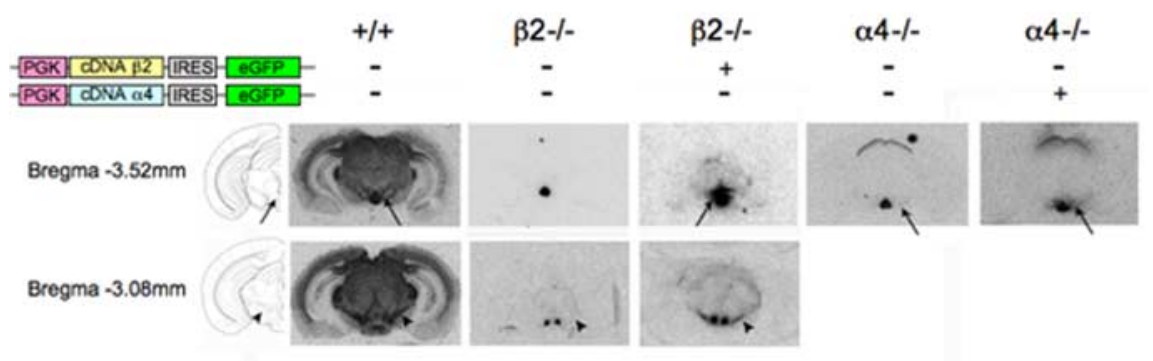

125 I-CtxMII

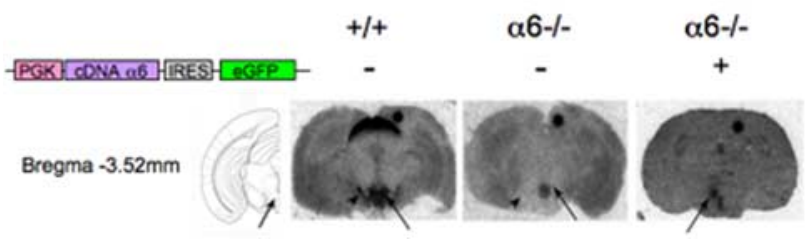

Figure 6. $\quad \boldsymbol{A}$, Lentiviral vectors used in the re-expression experiments Maps of lentiviral expression vectors. Diagrams of the three lentiviral vectors used in this study, between and including the LTR regions. LTR, long terminal repeat; RNA pack, genomic RNA packaging signal; RRE, rev response element; CPPT, central polypurine tract; CTS, central termination sequence; PGK, promoter of the mouse phosphoglycerate kinase gene; IRES2, internal ribosome entry sequence; eGFP, enhanced green fluorescent protein; WPRE, woodchuck hepatitis B virus post-transcriptional regulatory element; 3 ' -PPT, $3^{\prime}$-polypurine tract; $\Delta U 3$, deletion of the U3 portion of $3^{\prime}$-LTR. $\boldsymbol{B},{ }^{125}$ I-Epibatidine and ${ }^{125} \mid \alpha$-conotoxin MII autoradiography. Top: ${ }^{125}$-Epibatidine autoradiography, binding sites are shown in coronal sections from two different levels, VTA (Bregma $-3.52 \mathrm{~mm}$ ) and SN (Bregma $-3.08 \mathrm{~mm}$ ), in WT, $\beta 2-K 0, \alpha 4-K 0$ and vectorised mice. From left to right, wild-type (WT) signal in the VTA (arrow), in SN (arrow head), absence in the $\beta 2-K 0$ group, restoration in $\beta 2-V E C-V T A$ mice, absence of epibatidine binding in the $\alpha 4$-KO group, restoration in $\alpha 4$-VEC-VTA mice. Asterisk marks $\alpha 6 \beta 2^{*}$ and $\alpha 3 \beta 2^{*}$-nAChRs in the superior colliculus. Bottom: ${ }^{125}$ I-conotoxin Mll autoradiography, from left to right: Presence of $\alpha$-conotoxin MII binding sites in WT mice, absence in $\alpha 6$-K0 mice and unilateral restoration in $\alpha 6$-VEC-VTA mice. The restoration of $\alpha 6^{*}$ binding sites in vectorised $\alpha 6 \mathrm{KO}$ mice is illustrated with a brain injected unilaterally, the other hemisphere being used as control. Asterisk marks $\alpha 3 \beta 2^{*}-n A C h R s$ in the superior colliculus. Coronal drawings are modified from Paxinos and Franklin (2001).

validity of this new powerful experimental paradigm for a detailed in-depth genetic analysis of nicotine reinforcement in the mouse.

\section{References}

Alderson HL, Latimer MP, Winn P (2006) Intravenous self-administration of nicotine is altered by lesions of the posterior, but not anterior, pedunculopontine tegmental nucleus. Eur J Neurosci 23:2169-2175.

Avale ME, Faure P, Pons S, Robledo P, Deltheil T, David DJ, Gardier AM, Maldonado R, Granon S, Changeux JP, Maskos U (2008) Interplay of $\beta 2^{\star}$ nic- otinic receptors and dopamine pathways in the control of spontaneous locomotion. Proc Natl Acad Sci U S A 105:15991-15996.

Balfour DJ (2002) The neurobiology of tobacco dependence: a commentary. Respiration 69:7-11.

Benowitz NL (2001) Compensatory smoking of low-yield cigarettes. In: Risks associated with smoking cigarettes with low machinemeasured yields of tar and nicotine. (Burns DM, Shopland DR, Benowitz NL, eds), pp $39-$ 63. Bethesda, MD: US National Institutes of Health, National Cancer Institute.

Benowitz NL, Jacob P 3rd (1985) Nicotine renal excretion rate influences nicotine intake during cigarette smoking. J Pharmacol Exp Ther 234:153-155.

Besson M, David V, Suarez S, Cormier A, Cazala P, Changeux JP, Granon S (2006) Genetic dissociation of two behaviors associated with nicotine addiction: beta- 2 containing nicotinic receptors are involved in nicotine reinforcement but not in withdrawal syndrome. Psychopharmacology (Berl) 187:189-199.

Besson M, Granon S, Mameli-Engvall M, CloëzTayarani I, Maubourguet N, Cormier A, Cazala P, David V, Changeux JP, Faure P (2007) Long-term effects of chronic nicotine exposure on brain nicotinic receptors. Proc Natl Acad Sci U S A 104:8155-8160.

Blokhina EA, Kashkin VA, Zvartau EE, Danysz W, Bespalov AY (2005) Effects of nicotinic and NMDA receptor channel blockers on intravenous cocaine and nicotine self-administration in mice. Eur Neuropsychopharmacol 15:219-225.

Champtiaux N, Han ZY, Bessis A, Rossi FM, Zoli M, Marubio L, McIntosh JM, Changeux JP (2002) Distribution and pharmacology of $\alpha$-6-containing nicotinic acetylcholine receptors analyzed with mutant mice. J Neurosci 22:1208-1217.

Champtiaux N, Gotti C, Cordero-Erausquin M, David DJ, Przybylski C, Léna C, Clementi F, Moretti M, Rossi FM, Le Novère N, McIntosh JM, Gardier AM, Changeux JP (2003) Subunit composition of functional nicotinic receptors in dopaminergic neurons investigated with knockout mice. J Neurosci 23:7820-7829.

Changeux JP, Edelstein S (2005) Acetylcholine nicotinic receptors: from molecular biology to cognition. Paris: Odile Jacob.

Corrigall WA (1999) Nicotine self-administration in animals as a dependence model. Nicotine Tob Res 1:11-20.

Corrigall WA, Coen KM, Adamson KL (1994) Self-administered nicotine activates the mesolimbic dopamine system through the ventral tegmental area. Brain Res 653:278-284.

Corringer PJ, Le Novère N, Changeux JP (2000) Nicotinic receptors at the amino acid level. Annu Rev Pharmacol Toxicol 40:431-458.

Cossu G, Ledent C, Fattore L, Imperato A, Böhme GA, Parmentier M, Fratta W (2001) Cannabinoid CB1 receptor knockout mice fail to selfadminister morphine but not other drugs of abuse. Behav Brain Res 118:61-65.

Crombag HS, Gorny G, Li Y, Kolb B, Robinson TE (2005) Opposite effects of amphetamine self-administration experience on dendritic spines in the medial and orbital prefrontal cortex. Cereb Cortex 15:341-348.

Cunningham MG, McKay RD (1993) A hypothermic miniaturized stereotaxic instrument for surgery in newborn rats. J Neurosci Methods 47:105-114.

David V, Besson M, Changeux JP, Granon S, Cazala P (2006) Reinforcing 
effects of nicotine microinjections into the ventral tegmental area of mice: Dependence on cholinergic nicotinic and dopaminergic D1 receptors. Neuropharmacology 50:1030-1040.

Drenan RM, Nashmi R, Imoukhuede PI, Just H, McKinney S, Lester HA (2008) Subcellular trafficking, pentameric assembly and subunit stoichiometry of neuronal nicotinic $\mathrm{ACh}$ receptors containing fluorescently labeled \{alpha\}6 and \{beta\}3 subunits. Mol Pharmacol 73:27-41.

Exley R, Clements MA, Hartung H, McIntosh JM, Cragg SJ (2008) alpha6containing nicotinic acetylcholine receptors dominate the nicotine control of dopamine neurotransmission in nucleus accumbens. Neuropsychopharmacology 33:2158-2166.

Fattore L, Martellotta MC, Cossu G, Mascia MS, Fratta W (1999) CB1 cannabinoid receptor agonist WIN 55,212-2 decreases intravenous cocaine self-administration in rats. Behav Brain Res 104:141-146.

Fattore L, Martellotta MC, Cossu G, Fratta W (2000) Gammahydroxybutyric acid: an evaluation of its rewarding properties in rats and mice. Alcohol 20:247-256.

Fattore L, Cossu G, Martellotta MC, Deiana S, Fratta W (2001) Baclofen antagonises intravenous self-administration of gamma-hydroxybutyric acid in mice. Neuroreport 12:2243-2246.

Fattore L, Cossu G, Martellotta MC, Fratta W (2002) Baclofen antagonizes intravenous self-administration of nicotine in mice and rats. Alcohol Alcohol 37:495-498.

Granon S, Faure P, Changeux JP (2003) Executive and social behaviors under nicotinic receptor regulation. Proc Natl Acad Sci USA 100:9596-9601.

Grenhoff J, Aston-Jones G, Svensson TH (1986) Nicotinic effects on the firing pattern of midbrain dopamine neurons. Acta Physiol Scand 128:351-358.

Grottick AJ, Trube G, Corrigall WA, Huwyler J, Malherbe P, Wyler R, Higgins GA (2000) Evidence that nicotinic alpha(7) receptors are not involved in the hyperlocomotor and rewarding effects of nicotine. J Pharmacol Exp Ther 294:1112-1119.

Ikemoto S, Qin M, Liu ZH (2006) Primary reinforcing effects of nicotine are triggered from multiple regions both inside and outside the ventral tegmental area. J Neurosci 26:723-730.

Ivanova S, Greenshaw AJ (1997) Nicotine-induced decreases in VTA electrical self-stimulation thresholds: blockade by haloperidol and mecamylamine but not scopolamine or ondansetron. Psychopharmacology (Berl) 134:187-192.

Kassel JD, Greenstein JE, Evatt DP, Wardle MC, Yates MC, Veilleux JC, Eissenberg T (2007) Smoking topography in response to denicotinized and high-yield nicotine cigarettes in adolescent smokers. J Adolesc Health 40:54-60.

Klink R, de Kerchove d'Exaerde A, Zoli M, Changeux JP (2001) Molecular and physiological diversity of nicotinic acetylcholine receptors in the midbrain dopaminergic nuclei. J Neurosci 21:1452-1463.

Koob GF, Weiss F (1990) Pharmacology of drug self-administration. Alcohol 7:193-197.

Kuzmin A, Johansson B (2000) Reinforcing and neurochemical effects of cocaine: differences among C57, DBA, and 129 mice. Pharmacol Biochem Behav 65:399-406.

Kuzmin A, Zvartau E, Gessa GL, Martellotta MC, Fratta W (1992) Calcium antagonists isradipine and nimodipine suppress cocaine and morphine intravenous self-administration in drug-naive mice. Pharmacol Biochem Behav 41:497-500.

Kuzmin A, Semenova S, Zvartau EE, Van Ree JM (1996a) Enhancement of morphine self-administration in drug naive, inbred strains of mice by acute emotional stress. Eur Neuropsychopharmacol 6:63-68.

Kuzmin A, Semenova S, Ramsey NF, Zvartau EE, Van Ree JM (1996b) Modulation of cocaine intravenous self-administration in drug-naive animals by dihydropyridine $\mathrm{Ca} 2+$ channel modulators. Eur J Pharmacol 295:19-25.

Kuzmin AV, Semenova S, Gerrits MA, Zvartau EE, Van Ree JM (1997) Kappa-opioid receptor agonist U50,488H modulates cocaine and morphine self-administration in drug-naive rats and mice. Eur J Pharmacol 321:265-271.

Kuzmin AV, Gerrits MA, Zvartau EE, van Ree JM (2000) Influence of buprenorphine, butorphanol and nalbuphine on the initiation of intravenous cocaine self-administration in drug naive mice. Eur Neuropsychopharmacol 10:447-454.

Laviolette SR, van der Kooy D (2004) The neurobiology of nicotine addic- tion: bridging the gap from molecules to behaviour. Nat Rev Neurosci 5:55-65.

Ledent C, Valverde O, Cossu G, Petitet F, Aubert JF, Beslot F, Böhme GA, Imperato A, Pedrazzini T, Roques BP, Vassart G, Fratta W, Parmentier M (1999) Unresponsiveness to cannabinoids and reduced addictive effects of opiates in CB1 receptor knockout mice. Science 283:401-404.

Le Novère N, Zoli M, Changeux JP (1996) Neuronal nicotinic receptor alpha 6 subunit mRNA is selectively concentrated in catecholaminergic nuclei of the rat brain. Eur J Neurosci 8:2428-2439.

Le Novère N, Zoli M, Léna C, Ferrari R, Picciotto MR, Merlo-Pich E, Changeux JP (1999) Involvement of alpha6 nicotinic receptor subunit in nicotine-elicited locomotion, demonstrated by in vivo antisense oligonucleotide infusion. Neuroreport 10:2497-2501.

Le Novère N, Corringer PJ, Changeux JP (2002) The diversity of subunit composition in nAChRs: evolutionary origins, physiologic and pharmacologic consequences. J Neurobiol 53:447-456.

Lesscher HM, Hoogveld E, Burbach JP, van Ree JM, Gerrits MA (2005) Endogenous cannabinoids are not involved in cocaine reinforcement and development of cocaine-induced behavioural sensitization. Eur Neuropsychopharmacol 15:31-37.

Mameli-Engvall M, Evrard A, Pons S, Maskos U, Svensson TH, Changeux JP, Faure P (2006) Hierarchical control of dopamine neuron-firing patterns by nicotinic receptors. Neuron 50:911-921.

Mansvelder HD, McGehee DS (2000) Long-term potentiation of excitatory inputs to brain reward areas by nicotine. Neuron 27:349-357.

Mansvelder HD, Keath JR, McGehee DS (2002) Synaptic mechanisms underlie nicotine-induced excitability of brain reward areas. Neuron 33:905-919.

Martellotta MC, Kuzmin A, Zvartau E, Cossu G, Gessa GL, Fratta W (1995) Isradipine inhibits nicotine intravenous self-administration in drugnaive mice. Pharmacol Biochem Behav 52:271-274.

Martellotta MC, Cossu G, Fattore L, Gessa GL, Fratta W (1998a) Selfadministration of the cannabinoid receptor agonist WIN 55,212-2 in drug-naive mice. Neuroscience 85:327-330.

Martellotta MC, Cossu G, Fattore L, Gessa GL, Fratta W (1998b) Intravenous self-administration of gamma-hydroxybutyric acid in drug-naive mice. Eur Neuropsychopharmacol 8:293-296.

Martellotta MC, Balducci C, Fattore L, Cossu G, Gessa GL, Pulvirenti L, Fratta W (1998c) Gamma-hydroxybutyric acid decreases intravenous cocaine self-administration in rats. Pharmacol Biochem Behav 59:697-702.

Maskos U, Molles BE, Pons S, Besson M, Guiard BP, Guilloux JP, Evrard A, Cazala P, Cormier A, Mameli-Engvall M, Dufour N, Cloëz-Tayarani I, Bemelmans AP, Mallet J, Gardier AM, David V, Faure P, Granon S, Changeux JP (2005) Nicotine reinforcement and cognition restored by targeted expression of nicotinic receptors. Nature 436:103-107.

McGehee DS, Role LW (1995) Physiological diversity of nicotinic acetylcholine receptors expressed by vertebrate neurons. Annu Rev Physiol 57:521-546.

Naldini L, Blömer U, Gage FH, Trono D, Verma IM (1996) Efficient transfer, integration, and sustained long-term expression of the transgene in adult rat brains injected with a lentiviral vector. Proc Natl Acad Sci U S A 93:11382-11388.

Nashmi R, Dickinson ME, McKinney S, Jareb M, Labarca C, Fraser SE, Lester HA (2003) Assembly of $\alpha 4 \beta 2$ nicotinic acetylcholine receptors assessed with functional fluorescently labeled subunits: effects of localization, trafficking, and nicotine-induced upregulation in clonal mammalian cells and in cultured midbrain neurons. J Neurosci 23:11554-11567.

Nashmi R, Xiao C, Deshpande P, McKinney S, Grady SR, Whiteaker P, Huang Q, McClure-Begley T, Lindstrom JM, Labarca C, Collins AC, Marks MJ, Lester HA (2007) Chronic nicotine cell specifically upregulates functional $\alpha 4^{\star}$ nicotinic receptors: basis for both tolerance in midbrain and enhanced long-term potentiation in perforant path. J Neurosci 27:8202-8218.

Newhouse PA, Potter A, Singh A (2004) Effects of nicotinic stimulation on cognitive performance. Curr Opin Pharmacol 4:36-46.

Paterson NE, Semenova S, Gasparini F, Markou A (2003) The mGluR5 antagonist MPEP decreased nicotine self-administration in rats and mice. Psychopharmacology (Berl) 167:257-264.

Paxinos G, Franklin KBJ (2001) The mouse brain in stereotaxic coordinates, Ed 2. San Diego: Academic.

Peto R, Lopez AD, Boreham J, Thun M, Heath C Jr, Doll R (1996) Mortal from smoking worldwide. Br Med Bull 52:12-21. 
Picciotto MR, Zoli M, Léna C, Bessis A, Lallemand Y, Le Novère N, Vincent P, Pich EM, Brûlet P, Changeux JP (1995) Abnormal avoidance learning in mice lacking functional high-affinity nicotine receptor in the brain. Nature 374:65-67.

Picciotto MR, Zoli M, Rimondini R, Léna C, Marubio LM, Pich EM, Fuxe K, Changeux JP (1998) Acetylcholine receptors containing the beta2 subunit are involved in the reinforcing properties of nicotine. Nature 391:173-177.

Rahman S, Zhang J, Corrigall WA (2004) Local perfusion of nicotine differentially modulates somatodendritic dopamine release in the rat ventral tegmental area after nicotine preexposure. Neurochem Res 29:1687-1693.

Rasmussen T, Swedberg MD (1998) Reinforcing effects of nicotinic compounds: intravenous self-administration in drug-naive mice. Pharmacol Biochem Behav 60:567-573.

Rasmussen T, Fink-Jensen A (2000) Intravenous scopolamine is potently self-administered in drug-naive mice. Neuropsychopharmacology 22:97-99.

Rasmussen T, Sauerberg P, Nielsen EB, Swedberg MD, Thomsen C, Sheardown MJ, Jeppesen L, Calligaro DO, DeLapp NW, Whitesitt C, Ward JS, Shannon HE, Bymaster FP, Fink-Jensen A (2000) Muscarinic receptor agonists decrease cocaine self-administration rates in drug-naive mice. Eur J Pharmacol 402:241-246.

Rice ME, Cragg SJ (2004) Nicotine amplifies reward-related dopamine signals in striatum. Nat Neurosci 7:583-584.

Robinson SF, Grun EU, Pauly JR, Collins AC (1996) Changes in sensitivity to nicotine and brain nicotinic receptors following chronic nicotine and corticosterone treatments in mice. Pharmacol Biochem Behav 54:587-593.

Rose JE, Corrigall WA (1997) Nicotine self-administration in animals and humans: similarities and differences. Psychopharmacology (Berl) 130:28-40.

Salas R, Main A, Gangitano D, De Biasi M (2007) Decreased withdrawal symptoms but normal tolerance to nicotine in mice null for the alpha7 nicotinic acetylcholine receptor subunit. Neuropharmacology 53:863-869.

Salminen O, Drapeau JA, McIntosh JM, Collins AC, Marks MJ, Grady SR (2007) Pharmacology of alpha-conotoxin MII-sensitive subtypes of nic- otinic acetylcholine receptors isolated by breeding of null mutant mice. Mol Pharmacol 71:1563-1571.

Silagy C, Lancaster T, Stead L, Mant D, Fowler G (2004) Nicotine replacement therapy for smoking cessation. Cochrane Database Syst Rev 3:CD000146.

Solinas M, Panlilio LV, Antoniou K, Pappas LA, Goldberg SR (2003) The cannabinoid CB1 antagonist $N$-piperidinyl-5-(4-chlorophenyl)-1-(2,4dichlorophenyl)-4-methylpyrazole-3-carboxamide (SR-141716A) differentially alters the reinforcing effects of heroin under continuous reinforcement, fixed ratio, and progressive ratio schedules of drug selfadministration in rats. J Pharmacol Exp Ther 306:93-102.

Spano MS, Fattore L, Cossu G, Deiana S, Fadda P, Fratta W (2004) CB1 receptor agonist and heroin, but not cocaine, reinstate cannabinoidseeking behaviour in the rat. Br J Pharmacol 143:343-350.

Stolerman IP, Naylor C, Elmer GI, Goldberg SR (1999) Discrimination and self-administration of nicotine by inbred strains of mice. Psychopharmacology (Berl) 141:297-306.

Tapper AR, McKinney SL, Nashmi R, Schwarz J, Deshpande P, Labarca C, Whiteaker P, Marks MJ, Collins AC, Lester HA (2004) Nicotine activation of alpha $4^{*}$ receptors: sufficient for reward, tolerance, and sensitization. Science 306:1029-1032.

Tizabi Y, Copeland RL Jr, Louis VA, Taylor RE (2002) Effects of combined systemic alcohol and central nicotine administration into ventral tegmental area on dopamine release in the nucleus accumbens. Alcohol Clin Exp Res 26:394-399.

Tolu S, Nakatani H, Avale E, Pons S, Maskos U (2007) Towards a neuronal subtype-specific lentiviral vector system. Soc Neurosci Abstr 32:611.11.

Walters CL, Brown S, Changeux JP, Martin B, Damaj MI (2006) The beta2 but not alpha7 subunit of the nicotinic acetylcholine receptor is required for nicotine-conditioned place preference in mice. Psychopharmacology (Berl) 14:1-6.

Whiteaker P, McIntosh JM, Luo S, Collins AC, Marks MJ (2000) 125Ialpha-conotoxin MII identifies a novel nicotinic acetylcholine receptor population in mouse brain. Mol Pharmacol 57:913-925.

Zhang H, Sulzer D (2004) Frequency-dependent modulation of dopamine release by nicotine. Nat Neurosci 7:581-582.

Zoli M, Léna C, Picciotto MR, Changeux JP (1998) Identification of four classes of brain nicotinic receptors using $\beta 2$ mutant mice. J Neurosci 18:4461-4472. 